\title{
Predicting the effects of climate change on water yield and forest production in the northeastern United States
}

\author{
John D. Aber ${ }^{1, *}$, Scott V. Ollinger ${ }^{1}$, C. Anthony Federer ${ }^{2}$, Peter B. Reich ${ }^{3}$, \\ Michael L. Goulden ${ }^{4}$, David W. Kicklighter ${ }^{5}$, Jerry M. Melillo ${ }^{5}$, Richard G. Lathrop, $\mathbf{J r}^{6}$ \\ ${ }^{1}$ Complex Systems Research Center, Institute for the Study of Earth, Oceans and Space, University of New Hampshire, \\ Durham, New Hampshire 03824, USA \\ ${ }^{2}$ Northeastern Forest Experiment Station, U.S. Forest Service, Durham, New Hampshire 03824, USA \\ ${ }^{3}$ Department of Forest Resources, University of Minnesota, St. Paul, Minnesota 55108, USA \\ ${ }^{4}$ Department of Earth and Planetary Sciences, Harvard University, Cambridge, Massachusetts 02138, USA \\ ${ }^{5}$ The Ecosystem Center, Marine Biological Laboratory, Woods Hole, Massachusetts 02543, USA \\ ${ }^{6}$ Department of Natural Resources, Cook College Rutgers, New Brunswick, New Jersey 08903, USA
}

\begin{abstract}
Rapid and simultaneous changes in temperature, precipitation and the atmospheric concentration of $\mathrm{CO}_{2}$ are predicted to occur over the next century. Simple, well-validated models of ecosystem function are required to predict the effects of these changes. This paper describes an improved version of a forest carbon and water balance model (PnET-In) and the application of the model to predict stand-and regional-level effects of changes in temperature, precipitation and atmospheric $\mathrm{CO}_{2}$

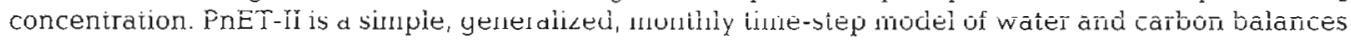
(gross and net) driven by nitrogen availability as expressed through foliar $\mathrm{N}$ concentration. Improvements from the original model include a complete carbon balance and improvements in the prediction of canopy phenology, as well as in the computation of canopy structure and photosynthesis. The model was parameterized and run for 4 forest/site combinations and validated against available data for water yield, gross and net carbon exchange and biomass production. The validation exercise suggests that the determination of actual water availability to stands and the occurrence or non-accurrence of soilbased water stress are critical to accurate modeling of forest net primary production (NPP) and net ecosystem production (NEP). The model was then run for the entire NewEngland/New York (USA) region using a $1 \mathrm{~km}$ resolution geographic information system. Predicted long-term NEP ranged from -85 to $+275 \mathrm{~g} \mathrm{C} \mathrm{m}^{-2} \mathrm{yr}^{-1}$ for the 4 forest/site combinations, and from -150 to $350 \mathrm{~g} \mathrm{C} \mathrm{m}^{-2} \mathrm{yr}^{-1}$ for the region, with a regional average of $76 \mathrm{~g} \mathrm{C} \mathrm{m}^{-2} \mathrm{yr}^{-1}$ A combination of increased temperature $\left(+6^{\circ} \mathrm{C}\right)$, decreased precipitation $(-15 \%)$ and increased water use efficiency (2x, due to doubling of $\mathrm{CO}_{2}$ ) resulted generally in increases in NPP and decreases in water yield over the region.
\end{abstract}

KEY WORDS: Foliar nitrogen - Photosynthesis - Respiration - Allocation - GIS - Regional analysis Validation - Transpiration. Water balance

\section{INTRODUCTION}

Rapid and simultaneous changes in several environmental factors controlling forest ecosystem function are predicted to occur over the next century (Mitchell et al. 1990). Among the most critical of these are tem-

\footnotetext{
•E-mail: jda@shooter.unh.edu
}

perature, precipitation and the atmospheric concentration of $\mathrm{CO}_{2}$ (reviews by Bazzaz 1990, Melillo et al. 1990, Mooney et al. 1991). Because we cannot perform factorial experiments with these variables in the field on intact ecosystems, we must rely on integrated models of ecosystem function to predict the ultimate effects of change on the future health and function of ecosystems (e.g. Burke et al. 1991, Raich et al. 1991, Rastetter et al. 1991, Running \& Nemani 1991). 
In 2 earlier papers (Aber \& Federer 1992, Aber et al. 1993a) we have discussed the need for simple, wellvalidated models of ecosystem function for application to issues of environmental change. The goal of such models should be to capture the most critical interactions between environmental drivers and ecosystem processes using the fewest possible and most readily available variables. Complex models of subsystems (e.g. photosynthesis) become unmanageably cumbersome and data-intensive if combined with similarly complex models of other important processes such as transpiration, respiration, allocation, decomposition and phenology. These complex processes often can be reduced to simpler and more generally applicable relationships when viewed from a higher level of resolution. Simple input parameters are needed if the model is to be applied over large regions rather than at just a few intensively studied research sites.

Validation is as critical as simplicity in convincing the scientific community that any individual model accurately represents some subset of forest ecosystem function. To this end, a model should be validated against as many field data sets as are available, representing as many processes as possible. Validation of models at the ecosystem level requires the existence of long-term measurements of whole-ecosystem function such as those currently being acquired under the U.S. National Science Foundation's Long-Term Ecological Research (LTER) Program.

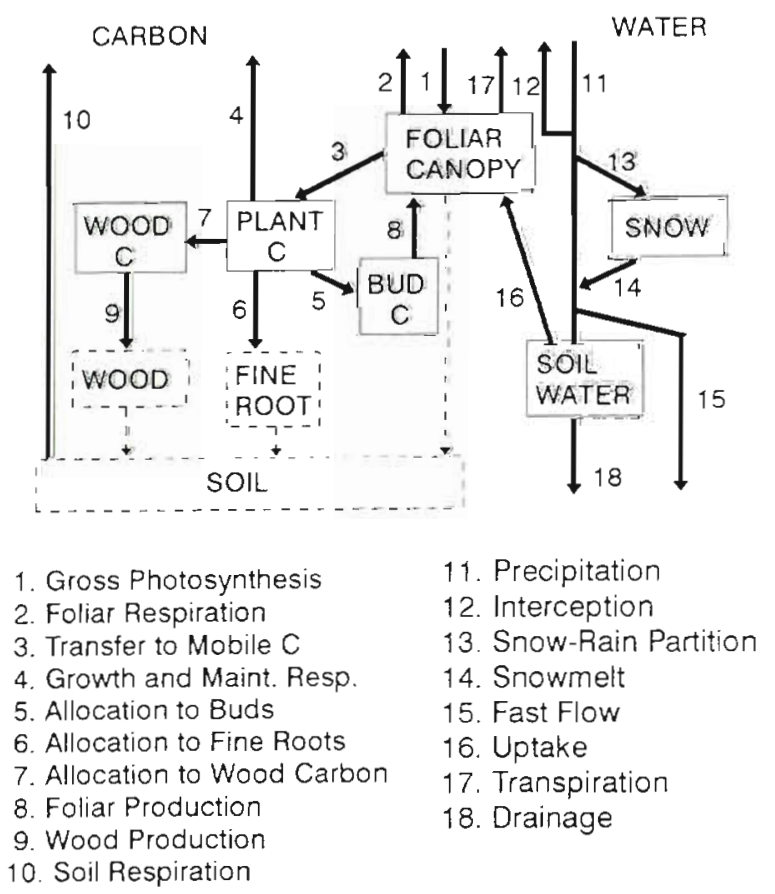

Fig. 1. Structure of PnET-II
The purposes of this paper are to: (1) present modifications of an existing model (PnET, Aber \& Federer 1992) which improve the photosynthesis routine and allow monthly estimation of ecosystem carbon and water balances, (2) validate this new version (PnET-II) against 2 unique sets of time series data on the carbon and water balances of northern U.S. forest ecosystems, (3) predict the individual and combined effects of changes in temperature, precipitation and atmospheric $\mathrm{CO}_{2}$ on water yield and forest production at 3 sites, and (4) extend model predictions to the New England/New York (USA) region by running the model within a geographic information system (GIS; Aber et al. 1993a, Ollinger et al. 1993, 1995, Lathrop \& Bognar 1994, Lathrop et al. 1994) which provides the climatic and vegetation parameters required. The site-specific time series data for water balances are from Watershed 6 at the Hubbard Brook Experimental Forest, New Hampshire (Likens et al. 1977, Federer et al. 1990). The total ecosystem carbon balance (net ecosystem production, NEP) data are from the Harvard Forest, Petersham, Massachusetts (Wofsy et al. 1993). Available data on net primary production (NPP) for both sites can be used as additional validation data.

\section{METHODS}

\section{Model structure}

General. The original PnET model calculated a monthly water balance and carbon gain (net photosynthesis) but allocation of carbon to respiration and net primary production (NPP) occurred only at the end of each year. PnET-II retains the simple structure of the original PnET model, but adds a series of algorithms for carbon allocation and respiration which allow the calculation of monthly carbon balances (Fig. 1). In addition, a growing-degree-day driver has been added to control the phenology of canopy development and senescence, and the timing of wood growth and growth respiration. Finally, improvements in the description of canopy structure and photosynthesis are incorporated from a validated daily time step model (PnET-Day: Aber et al. 1995).

The computational structure of the model consists of 6 subroutines. Five of these are executed monthly in the following order: AtmEnviron [calculates vapor pressure deficit (VPD) and growing-degree-days], Psn (establishes leaf area and calculates potential photosynthesis in the absence of water stress), WaterBal (calculates water balance, degree of water stress and actual net photosynthesis), AllocateMo (calculates plant respiration, wood growth and respiration and allocation of carbon to roots) and SoilResp (calculates 
$\mathrm{CO}_{2}$ flux from soils). The sixth routine, AllocateYr, is called at the end of the growing season and allocates accumulated carbon to buds for next year's foliar production and to storage in wood for next year's wood production. Variable names used throughout this paper are the same as those used in the model code, which is written in QuickBasic and is available from the first author

Carbon allocation. Annual: PnET-II simulates determinate foliar and wood growth by allocating carbon from reserves accumulated during a given year (present as total $\mathrm{C}$ in PlantC) to buds (BudC) and a wood storage pool (WoodC) for use in growth in the following year. The maximum foliar mass for next year (MaxFolMass) is calculated as:

MaxFolMass $\left(\mathrm{g} \mathrm{m}^{-2}\right)=$ MeanAnnFolMass $[1+$ FolRelGrowMax (1 - LRatio)]

where MeanAnnFolMass is this year's mean foliar mass during the growing season, FolRelGrowMax is a value defining the maximum relative annual growth rate in total canopy foliar mass from one year to the next and LRatio is the ratio of maximum foliar mass this year to that which would occur if the canopy made full use of all available light (lowest foliar layer at or below light compensation point). This effectively provides for asymptotic growth of total foliar biomass to the maximum allowed by light, and for recovery to that level following reductions in leaf mass due to drought. The amount of carbon required to produce this foliar mass is transferred from PlantC to BudC.

Annual allacation to wood carbon (WoodC) is:

WoodC $\left(\mathrm{g} \mathrm{C} \mathrm{m}^{-2}\right)=$ PlantC $(1-$ PlantCReserveFrac $)$ (2)

where PlantCReserveFrac (range: 0 to 1 ) specifies the fraction of remaining PlantC (after allocation to BudC) which is held in reserve. This reflects the continuing presence of carbon reserves in trees for recreating foliage and roots following damage or defoliation. In the model this has the effect of damping year-to-year fluctuations in wood production. A final calculation determines whether the ratio of WoodC to BudC is above the parameter MinWoodFolRatio. If not, carbon is shifted from BudC to WoodC to maintain this ratio. The purpose of this calculation is to disallow foliar production in the absence of enough wood production to provide support and transport for that foliage. As in the original PnET model, allocation to wood production has the lowest priority and is least constrained by the model structure. Thus, validation of estimated wood production values is the most rigorous test of the carbon allocation routines. None of the parameter values have been 'tuned' or calibrated to achieve agreement between predicted and observed values.
Monthly: Foliar and wood production are driven by the accumulation of growing-degree-days (sum of daily mean temperatures above $0^{\circ} \mathrm{C}$, beginning $1 \mathrm{Jan}$ uary each year). Two new input variables (GDDFolStart and GDDFolEnd) define the growing-degree-day sums at which foliar growth begins and ends. BudC is transferred to new foliage production as a linear function of accumulated growing-degree-days between these values. At the time of foliage production, there is an associated growth respiration cost (FolGRespMo) equal to $25 \%$ (GRespFrac) of the carbon going to foliar growth. This is drawn from the plant mobile carbon (PlantC) pool. An analogous set of calculations occur for the timing and respirational cost of wood production, with GDDWoodStart and GDDWoodEnd describing the period in which carbon is transferred from WoodC to wood production.

The total amount of carbon allocated to roots for both growth and respiration is calculated as a linear function of foliar production using an equation (coefficients RootAllocA, RootAllocB) similar to that of Raich \& Nadelhoffer (1989) as described in the initial PnET paper (Aber \& Federer 1992). This demand is met from the current carbon accumulation in the plant (PlantC). It is assumed that the ratio of carbon allocated within roots to growth and to maintenance respiration are equal (RootMRespFrac $=1$ ) and that root growth has an associated $25 \%$ growth respiration cost. It should be noted that PnET-II does not track total accumulation, turnover and litter production from wood and fine root compartments. Foliar and wood respiration terms are part of the monthly carbon balance (see below), but root respiration terms are subsumed into the soil respiration value. Thus allocation to fine roots affects only the amount of carbon remaining in the plant mobile pool (PlantC) at the end of the growing season and hence the allocations to foliar and wood production in the following year.

Monthly carbon balance. The monthly carbon balance is calculated as:

$\begin{aligned} \text { NetCBal }= & \text { NetPsnMo }- \text { FolGRespMo }- \text { WoodMRespMo } \\ & - \text { WoodGRespMo }- \text { SoilRespMo }\end{aligned}$

where NetCBal is the NEP for the month, NetPsnMo is net photosynthesis, FolGRespMo is foliar growth respiration, WoodMRespMo and WoodGRespMo are wood maintenance and growth respiration, respectively, and SoilRespMo is the total soil respiration for the month. Foliar maintenance respiration is included in the net photosynthesis term. All values are in $\mathrm{g} \mathrm{C} \mathrm{m}^{-2} \mathrm{mo}^{-1}$.

Monthly net photosynthesis and foliar growth respiration: Equations for the phenology of canopy display and for calculating potential net photosynthesis (in the absence of water stress) for a given set of canopy and environmental conditions are identical to 
those presented for the daily model (PnET-Day: Aber et al. 1995). Those equations are used here at a monthly rather than daily time step, assuming an average day per month as represented by mean monthly climatic values (see Aber et al. 1995 for discussion on effects of aggregation).

Water balance calculations and the determination of degree of water stress occur in the WaterBal routine as in the previous version of the model (Aber \& Federer 1992). The degree of water stress is used to reduce potential net photosynthesis to realized net photosynthesis, which is transferred to the plant mobile carbon pool (PlantC).

Wood respiration: Calculations of monthly wood growth and growth respiration are analogous to those for foliage. At the end of each growing season, carbon is transferred from PlantC to WoodC to drive next year's wood growth. Growing-degree-day totals for initiating and concluding wood growth are specified by the variables GDDWoodStart and GDDWoodEnd. The transfer of carbon from WoodC to wood production occurs linearly with the accumulation of growingdegree-days between these 2 values. Wood growth respiration is an additional $25 \%$ of carbon in wood production for any month and is drawn from the PlantC pool. Wood maintenance respiration is calculated monthly as a constant fraction of gross photosynthesis (Ryan 1991) determined by the input variable WoodMRespFrac, and is also drawn from the PlantC pool.

Soil respiration: This routine was not present in the original model and is included here to allow a systemlevel carbon balance calculation. It does not contain a complete soil carbon budget which would be driven by litter deposition and associated decomposition terms. Rather, it uses a generalized soil respiration equation developed for temperate zone forests by Kicklighter et al. (1994). Soil respiration is assumed to include both microbial respiration associated with decomposition and respiration by live roots. That equation, derived using measured, plot-level soil $\mathrm{CO}_{2}$ flux data from a wide variety of sites, is:

$$
\text { Soil respiration }\left(\mathrm{g} \mathrm{C} \mathrm{m}^{-2} \mathrm{mo}^{-1}\right)=27.46 \mathrm{e}^{0.06844 t}
$$

where $t$ is the mean monthly temperature $\left({ }^{\circ} \mathrm{C}\right)$. Data from the Harvard Forest site represent approximately $24 \%$ of the total used to derive this equation. The remaining data come from a widely distributed set of temperate zone forests (see Kicklighter et al. 1994 for tull description).

Limitations of structure. The structure described here for PnET-II allows estimation of monthly and annual carbon and water balances using a few specified variables (discussed in next section). However, it does not represent a full, integrated carbon cycling model in that there is no feedback between biomass production and the production and decomposition of litter. System NEP is calculated as the balance between net photosynthesis and the sum of several respiration terms. There is no feedback between the production and soil respiration estimates. This means that while the model can predict current ecosystem NEP, it cannot, for example, predict NEP under a warmer climate, as the higher predicted soil respiration rate would be decoupled from existing feedbacks between production and decomposition.

\section{Model parameterization}

For validation runs, site-specific predictions, and regional predictions, it was necessary to develop input data sets for 4 vegetation types: (1) a northern hardwood deciduous forest at the Hubbard Brook Experimental Forest in north-central New Hampshire, (2) a red oak-red maple forest at the Harvard Forest in central Massachusetts, (3) a red pine plantation at the Harvard Forest, and (4) a generic spruce-fir data set for application to the area in this forest type across the northeast region.

Model changes described above increase the number of parameters required to run the model to 35 (Table 1). Of these, 16 vary among forest types (Table 2). Differences between the 2 hardwood sites reflect measured differences in foliar $\mathrm{N}$ concentration, and the fact that the Harvard Forest site is dominated by ring-porous species (mainly oaks) which produce springwood at the same time as foliage, while nor thern hardwoods are dominated by diffuse porous species which produce springwood after foliage. GDDFolStart and GDDFolEnd were calculated from mean climatic data based on an observed mid-May completion of leaf-out at the Harvard Forest, end-of-May completion at Hubbard Brook, and mid-summer completion in the evergreens.

Two different parts of the Harvard Forest (called 'chronic N' and 'tower' areas) were used for model validation. The chronic $N$ plots are the site of a long-term, low-level $\mathrm{N}$ amendment experiment (Aber et al. 1993b, Magill et al. unpubl.). Tower measurements are taken in the vicinity of the eddy correlation tower used for daily carbon balance measurements (Wofsy et al. 1993). The deciduous stands in these areas have different foliar $N$ concentrations. The control hardwood chronic $N$ plot has a whole-canopy foliar $N$ concentration of only $1.9 \%$, a relatively low value for this type of forest. Our best estimate of foliar $N$ concentrations in the forests around the tower site is derived from remote sensing data (M. E. Martin \& J. D. Aber unpubl.) and is about $2.2 \%$. 
Table 1. Input parameters required to run the PnET-II model. •Variables which vary between sites (see Table 2 for values)

\begin{tabular}{|c|c|c|}
\hline Name & Definition (units) & Value \\
\hline \multicolumn{3}{|c|}{ Site and soil variables } \\
\hline lat & Latitude (degrees) & • \\
\hline WHC & Water holding capacity, plant available water $(\mathrm{cm})$ & 12 \\
\hline \multicolumn{3}{|l|}{ Canopy variables } \\
\hline $\mathrm{k}$ & Canopy light attenuation constant (no units) & $\cdot$ \\
\hline FolNCon & Foliar nitrogen $(\%)$ & • \\
\hline FolReten & Foliage retention time (yr) & - \\
\hline SLWMax & Specific leaf weight at top of canopy $\left(\mathrm{g} \mathrm{m}^{-2}\right)$ & $\cdot$ \\
\hline SLWdel & Change in SLW with increasing foliar mass above $\left(\mathrm{g} \mathrm{m}^{-2} \mathrm{~g}^{-1}\right)$ & · \\
\hline FolRelGrowMax & Maximum relative growth rate for foliage $\left(\% \mathrm{yr}^{-1}\right)$ & 0.3 \\
\hline GDDFolStart & Growing-degree-days at which foliar production begins & $\cdot$ \\
\hline GDDFolEnd & Growing-degree-days at which foliar production ends & • \\
\hline GDDWoodStart & Growing-degree-days at which wood production begins & • \\
\hline GDDWoodEnd & Growing-degree-days at which wood production ends & $\cdot$ \\
\hline \multicolumn{3}{|c|}{ Photosynthesis variables } \\
\hline AmaxA & Intercept fof relationship between foliar $\mathrm{N}$ and max photosynthetic rate & ' \\
\hline AmaxB & Slope $\quad\left\{A_{\max }\left(\mu \mathrm{mol} \mathrm{CO} \mathrm{CO}^{-2}\right.\right.$ leaf $\left.\mathrm{s}^{-1}\right)$ & ' \\
\hline BaseFolRespFrac & Respiration as a fraction of maximum photosynthesis & 0.1 \\
\hline HalfSat & Half saturation light level $\left(\mu \mathrm{mol} \mathrm{m} \mathrm{m}^{-2} \mathrm{~s}^{-1}\right)$ & 200 \\
\hline AmaxFrac & Daily $A_{\max }$ as a fraction of early morning instantaneous rate & 0.76 \\
\hline PsnTOpt & Optimum temp for photosynthesis $\left({ }^{\circ} \mathrm{C}\right)$ & $\cdot$ \\
\hline PsnTMin & Minimum temp. for photosynthesis $\left({ }^{\circ} \mathrm{C}\right)$ & $\cdot$ \\
\hline RespQ10 & $Q_{10}$ value for foliar respiration & 2 \\
\hline \multicolumn{3}{|c|}{ Water balance variables } \\
\hline DVPD 1 & Coefficients for converting VPD to DVPD $\left(\mathrm{kPa}^{-1}\right)$ & 0.05 \\
\hline DVPD2 & & 2 \\
\hline PrecIntFrac & Fraction of precipitation intercepted and evaporated & . \\
\hline WUEConst & Constant in equation for water use efficiency (WUE) as a function of VPD & 10.9 \\
\hline FastFlowFrac & Fraction of water inpuits lost directiy io cudanage & 0.1 \\
\hline f & Soil water release parameter & 0.04 \\
\hline \multicolumn{3}{|c|}{ Carbon allocation variables } \\
\hline CFracBiomass & Carbon as fraction of foliage mass & 0.45 \\
\hline RootAllocA & Intercept fof relationship between & 0 \\
\hline RootAllocB & Slope foliar and root allocation & 2 \\
\hline GRespFrac & Growth respiration, fraction of allocation & 0.25 \\
\hline RootMRespFrac & Ratio of fine root maintenance respiration to biomass production & 1 \\
\hline WoodMRespA & Wood maintenance respiration as a fraction of gross photosynthesis & 0.07 \\
\hline PlantCReserveFrac & Fraction of PlantC held in reserve after allocation to BudC & 0.75 \\
\hline MinWoodFolRatio & Minimum ratio of carbon allocation to wood and foliage & $\cdot$ \\
\hline \multicolumn{3}{|c|}{ Soil respiration variables } \\
\hline SoilRespA & Intercept fof relationship between mean monthly temperature & 27.46 \\
\hline SoilRespB & Slope $\quad$ and soil respiration $\left(\mathrm{g} \mathrm{C} \mathrm{m}^{-2} \mathrm{mo}^{-1}\right)$ & 0.06844 \\
\hline
\end{tabular}

\section{Validation}

The simultaneous validation of model predictions against several measures of ecosystem function for more than one ecosystem provides a more rigorous test of model accuracy than comparison with a single output variable for a single system. The rigorousness of the validation exercise is also increased by testing against output variables which represent processes which are strongly linked in the model, such as photo- synthesis and transpiration. This makes it less likely, but not impossible, that the right answer is achieved through sets of compensating errors.

Here we have validated PnET-II using data on monthly carbon balance (Wofsy et al. 1993, Aber et al. 1995) and annual foliar and wood production (Magill et al. unpubl.) at the Harvard Forest, and monthly streamflow (Federer et al. 1990) and annual foliar and wood production (Gosz et al. 1972, Whittaker et al. 1974, Covington \& Aber 1980) at Hubbard Brook. To 
Table 2. Actual values used for the starred parameters in Table 1. Growing-degree-day parameters derived from phenology information for each forest type. Data sources for remaining parameters described in Aber \& Federer (1992) and Aber et al.

(1995), with additional spruce-fir data from Whiteface Mountain, New York, may be found in Johnson \& Lindberg (1992)

\begin{tabular}{|c|c|c|c|c|}
\hline \multirow[t]{2}{*}{ Parameter } & \multirow[t]{2}{*}{ Hubbard Brook } & \multicolumn{2}{|c|}{ Harvard Forest } & \multirow[t]{2}{*}{ Spruce-fir } \\
\hline & & HDWD & Pine & \\
\hline lat $\left({ }^{\circ}\right)$ & 44 & 42 & 42 & 44 \\
\hline $\mathrm{k}$ & 0.58 & 0.58 & 0.5 & 0.5 \\
\hline FolNCon $(\%)$ & 2.4 & $1.9(2.2)^{\mathrm{a}}$ & 1.2 & 0.8 \\
\hline FolReten (yr) & 1 & 1 & 2.25 & 4 \\
\hline SLWMax & 100 & 100 & 200 & 170 \\
\hline SLWdel & 0.2 & 0.2 & 0 & 0 \\
\hline GDDFolStart & 100 & 100 & 900 & 300 \\
\hline GDDFolEnd & 900 & 900 & 1600 & 1400 \\
\hline GDDWoodStart & 900 & 100 & 900 & 300 \\
\hline GDDWoodEnd & 1600 & 900 & 1600 & 1400 \\
\hline AmaxA & -46.0 & -46.0 & 5.3 & 5.3 \\
\hline AmaxB & 71.9 & 71.9 & 21.5 & 21.5 \\
\hline PsnTOpt & 24 & 24 & 24 & 20 \\
\hline PsnTMin & 4 & 4 & 4 & 0 \\
\hline PrecintFrac & 0.11 & 0.11 & 0.15 & 0.15 \\
\hline MinWoodFolRatio & 1.5 & 1.5 & 1.25 & 1.25 \\
\hline
\end{tabular}

run the model regionally, a data set for spruce-fir forests was developed by calibration against the data in Johnson \& Lindberg (1992). As no independent data for testing the spruce-fir predictions were available, this is not a validation.

\section{Predicted responses to climate change}

Four change scenarios were run for each site, representing the individual and combined changes in precipitation, temperature and atmospheric $\mathrm{CO}_{2}$ concentrations predicted for this region (Mitchell et al. 1990). Those changes include a $6^{\circ} \mathrm{C}$ increase in temperature (realized here as increases in both maximum and minimum temperature for all months), a $15 \%$ decrease in precipitation and a doubling of $\mathrm{CO}_{2}$. Increases in $\mathrm{CO}_{2}$ can have 2 effects: an increase in the absolute rate of photosynthesis, and an increase in water-use efficiency (Bazzaz 1990, Mooney et al. 1991). The sustainability of long-term increases in photosynthesis and growth has been questioned based on limitations imposed by nutrient availability (e.g. Tissue \& Oechel 1987. Rastetter et al. 1991). For this reason, we have not included any direct effects on photosynthetic rate, but rather only on water use efficiency. A doubling of $\mathrm{CO}_{2}$ is assumed to result in a doubling of water-use efficiency. Harvard Forest and Hubbard Brook runs used the complete time series climate data available for each site, modified as indicated by the treatment. The spruce-fir run used scenario modifications of calculated (Ollinger et al. 1993) mean climate.

We did not attempt to predict long-term changes in NEP (total ecosystem carbon balance) in response to changes in climate. In PnET-II, production and decomposition are uncoupled through the use of the temperature-soil respiration equation. This equation is an empirical result reflecting the current state of soils in the region. Modeled increases in temperature would result in large increases in soil respiration and strongly negative carbon balances. It is very unlikely that such negative balances could actually be sustained under field conditions for any extended period. Rather, a downward adjustment of the temperature-respiration relationship would be expected as soil reserves of labile organic matter were depleted.

\section{Interaction with a regional GIS}

For regional applications, PnET-II was run in conjunction with a $1 \mathrm{~km}$ resolution GIS covering New England and eastern New York State. For each cell, elevation (USGS 1987) and vegetation type (Lathrop \& Bognar 1994) were read from the appropriate data planes and climate variables were calculated as a function of latitude, longitude and elevation (Ollinger et al. (1995). Forest cover types were classified as hardwood, 
spruce-fir, mixed hardwood/spruce-fir and mixed hardwood/pine. Cells containing mixed forest types were run twice, with the final value being a weighted average of the hardwood and conifer values obtained. For mixed hardwood/spruce-fir forests, we assumed a hardwood:softwood ratio of 40:60. For hardwood/pine this ratio was 60:40 (estimated by comparing the vegetation map with USDA Forest Service Forest Inventory Analysis data; Beltz et al. 1992). Attempts to validate a data plane for holding capacity of soil water available to plants, derived from STATSGO data (U.S. Soil Conservation Service 1991, Lathrop et al. 1995), showed little agreement between derived values and the finer scale data from which STATSGO was derived. Because of this, we have used a regional average of $12 \mathrm{~cm}$ available water holding capacity for all sites.

\section{RESULTS AND DISCUSSION}

\section{Validation}

\section{Harvard Forest}

Biomass production has been measured in the 2 control chronic $\mathrm{N}$ plots (a red oak-red maple stand and a red pine plantation; Magill et al. unpubl.). PnET-II predictions for wood and foliar production on these plots are within $5 \%$ of measured values (Table 3 ). The relatively low productivity values for the hardwood control stand reflect the relatively low measured foliar $\mathrm{N}$ concentration $(1.9 \%)$ in this stand.

Monthly estimates of gross and net carbon exchange (GCE and NCE) predicted by PnET-II differ significantly from measured rates, especially in 1991 and 1993 (Fig. 2). A major factor causing this difference is the prediction by the model of reductions in photosynthesis due to water stress in these 2 years. There is no indication of water stress in the tower data [no significant mid-season depression in carbon gain beyond those caused by variation in light, VPD (Vapor Pressure Deficit) and temperature], and a canopy-level model of daily GCE (Aber et al. 1995) which assumed no soil-based water stress matched closely with the tower data. Model-predicted maximum soil water draw-down during both 1991 and 1993, in the absence of water stress, is over $18 \mathrm{~cm}$, while the regionally specified water holding capacity is only $12 \mathrm{~cm}$. The results would suggest either that transpiration is overestimated or that the forest immediately around the tower either had access to inflows of ground water or a perched water table, or had significantly higher water holding capacity. Water yield results reported below for Hubbard Brook argue against overestimation of
Table 3. Foliar and wood production $\left(\mathrm{g} \mathrm{C} \mathrm{m}^{-2} \mathrm{yr}^{-1}\right)$ as estimated by PnET-II for the hardwood and pine control stands at the Harvard Forest, and measured values from the 'chronic N' experiment at the Harvard Forest. Both predicted and measured values are means for 5 years (1988 to 1993, data from Magill et al. unpubl.)

\begin{tabular}{|lcccc|}
\hline & \multicolumn{2}{c}{ PaET-Il } & \multicolumn{2}{c|}{ Measured } \\
& $\begin{array}{l}\text { Foliar } \\
\text { NPP }\end{array}$ & $\begin{array}{c}\text { Wood } \\
\text { NPP }\end{array}$ & $\begin{array}{c}\text { Foliar } \\
\text { NPP }\end{array}$ & $\begin{array}{c}\text { Wood } \\
\text { NPP }\end{array}$ \\
\hline Hardwoods & 299 & 532 & 287 & 505 \\
Red pine & 315 & 390 & 316 & 377 \\
\hline
\end{tabular}

transpiration, unless water use efficiency varies significantly between these 2 sites. The potential for the stand in the tower area to draw on ground water reserves and so augment water availability is currently being investigated. When run with unlimited soil water availability (no soil water stress) PnET-Il agreed with measured GCE to within the errors of data aggregation (Fig. 2a; Aber et al. 1995). Remaining differences between predicted and observed GCE may result from the use of different soil respiration equations in the 2 data sets. GCE is calculated from measured NCE at the tower using a site-specific soil respiration equation which differs from the equation developed for regional applications by Kicklighter et al. (1994).

With water stress removed, predicted and measured total annual net carbon flux differ by less than $70 \mathrm{~g} \mathrm{C}$ $\mathrm{m}^{-2} \mathrm{yr}^{-1}$ (Table 4 ), or about $7 \%$ of the total annual gross carbon flux. However, differences for certain individual months (Fig. 2b) still exceed 50\%. The large difference in summer of 1993 may relate in part to the large differences in the previous winter. Ecosystem respiration was higher during the winter of 1993 than during 1991 and 1992, possibly reflecting the effects of a heavy snowpack on soil frost. If higher soil respiration is due to over-winter decomposition of labile organic matter deposited in the fall, this could result in lower litter/soil respiration the following summer, thus increasing mid-summer NEP and the differences

Table 4. Predicted (PnET-II) and measured (eddy correlation) total annual net carbon exchange for the tower site at the Harvard Forest. Two PnET-II runs are shown, with and without water stress. All values in $\mathrm{g} \mathrm{C} \mathrm{m}^{-2} \mathrm{yr}^{-1}$

\begin{tabular}{|lccc|}
\hline Source & & Year & \\
& 1991 & 1992 & 1993 \\
\hline Tower & 273 & 292 & 180 \\
PnET (with water stress) & 131 & 200 & -15 \\
PnET (without water stress) & 314 & 244 & 248 \\
\hline
\end{tabular}



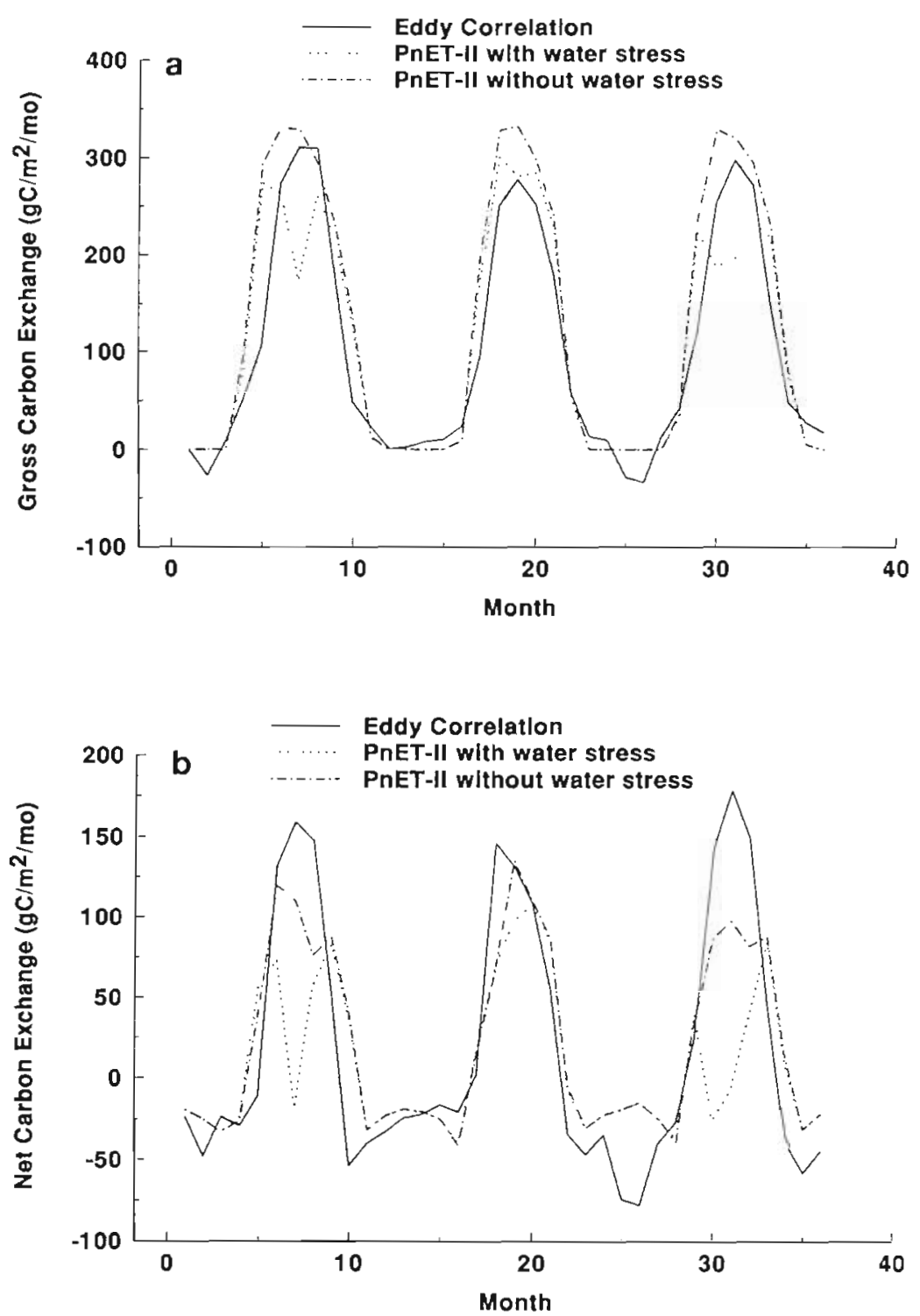

Fig. 2. Comparison of monthly net ecosystem carbon balances at the Harvard Forest as estimated by eddy-correlation measurements (Wofsy et al. 1993) and by PnET-II: (a) gross carbon exchange, (b) net carbon exchange. The 2 PnET-II runs are with and without water stress (see text for discussion) between predicted and observed shown here. PnET-II does not capture the effect of deep snow covers in insulating soils and increasing winter soil respiration.

\section{Hubbard Brook}

Predicted foliar and wood production at Hubbard Brook (Table 5) can be compared with data for 2 periods (1956-1960 and 1961-1965) for which these rates were estimated in the field by allometric techniques (Whittaker et al. 1974). The second period was one of extreme drought in the northeastern U.S. and would be expected to result in increased water stress and decreased forest growth. Wood production here includes all above- and below-ground production of woody material, including branches, twigs, root crowns and woody roots. Measured values are given for the low-elevation zone nearest to weather station 1, from which the climate data are drawn. Predictions for wood production are within 10 to $15 \%$ of measured values and do reflect the measured decline in wood production during the dry period. Predicted foliar production does not show such a decline, and the predicted values are between the values measured for the 2 periods. It should be noted that the allometric method predicts foliar production from wood production such that the two must vary in tandem. In contrast, PnET-II gives first priority to foliar production, allocating remaining plant mobile carbon, after bud production (BudC), to next year's wood production (WoodC). There is no

Table 5. Predicted and measured foliar and woody biomass (total of above- and below-ground) production for the Hubbard Brook forest ecosystem. All data are for the lowest elevation zones in Watershed 6 at Hubbard Brook, which is dominated by deciduous species. The PnET-II run specified all deciduous species. All values in $\mathrm{g}$ biomass $\mathrm{m}^{-2} \mathrm{yr}^{-1}$

\begin{tabular}{|c|c|c|c|c|c|c|c|}
\hline \multirow[t]{2}{*}{ Years } & \multicolumn{3}{|c|}{ Measured } & \multicolumn{3}{|c|}{ PnEt-II predicted } & \multirow[t]{2}{*}{ Source } \\
\hline & Foliage & Wood & Total & Foliage & Wood & Total & \\
\hline $1956-60$ & 374 & 921 & 1295 & 326 & 1055 & 1376 & Whittaker et al. (1974) \\
\hline $1961-65$ & 294 & 761 & 1055 & 316 & 891 & 1207 & Whittaker et al. (1974) \\
\hline 1968 & 316 & - & - & 306 & - & - & Gosz et al. (1972) \\
\hline 1969 & 273 & - & - & 295 & - & - & Gosz et al. (1972) \\
\hline 1974 & 296 & - & - & 332 & - & - & Covington \& Aber (1980) \\
\hline
\end{tabular}


independent verification that foliar production in the field actually decreased from the first to the second period. Three additional foliar production values measured as litter fall (Table 5) are all lower than the $374 \mathrm{~g} \mathrm{~m}^{-2} \mathrm{yr}^{-1}$ predicted by allometric techniques for 1956-1960, and are similar to values predicted by the model.

Predicted and observed mean monthly streamflow at Hubbard Brook for the period 1957 to 1990 do not differ significantly in any month (Fig. 3a). Time series data for specific years also show generally good agreement in both the timing and magnitude of seasonal changes in flow in both wet and dry years (Fig. 3b), with the biggest discrepancies occurring during the spring snowmelt period. As soils are always completely recharged during this period, these differences do not affect the carbon balance portions of the model. Regressing predicted versus observed data for all months (Fig. 3c) yields an $\mathrm{R}^{2}$ of 0.73 and a statistically nonsignificant intercept. The improvement in prediction of streamflow between PnET and PnET-II is due to the more accurate, continuous seasonal simulation of canopy development and senescence allowed by the growing-degree-day driver.

\section{Spruce-fir}

An additional data set was developed for the spruce-fir forest type found in the far northern and high elevation areas of the northeastern U.S. (Table 2). In this case, measured production data from Johnson \& Lindberg (1992) were used as targets for a calibration exercise in which foliar retention time and leaf specific weight were manipulated to achieve close agreement with measured data. Resulting values for these variables appear reasonable, and result in less than a $10 \%$ difference between measured and modeled values (Table 6). By contrast, data for the Hubbard Brook and Harvard Forest runs were not manipulated in any way to improve the agreement between predicted and observed values, and so those results represent a true validation of the model.
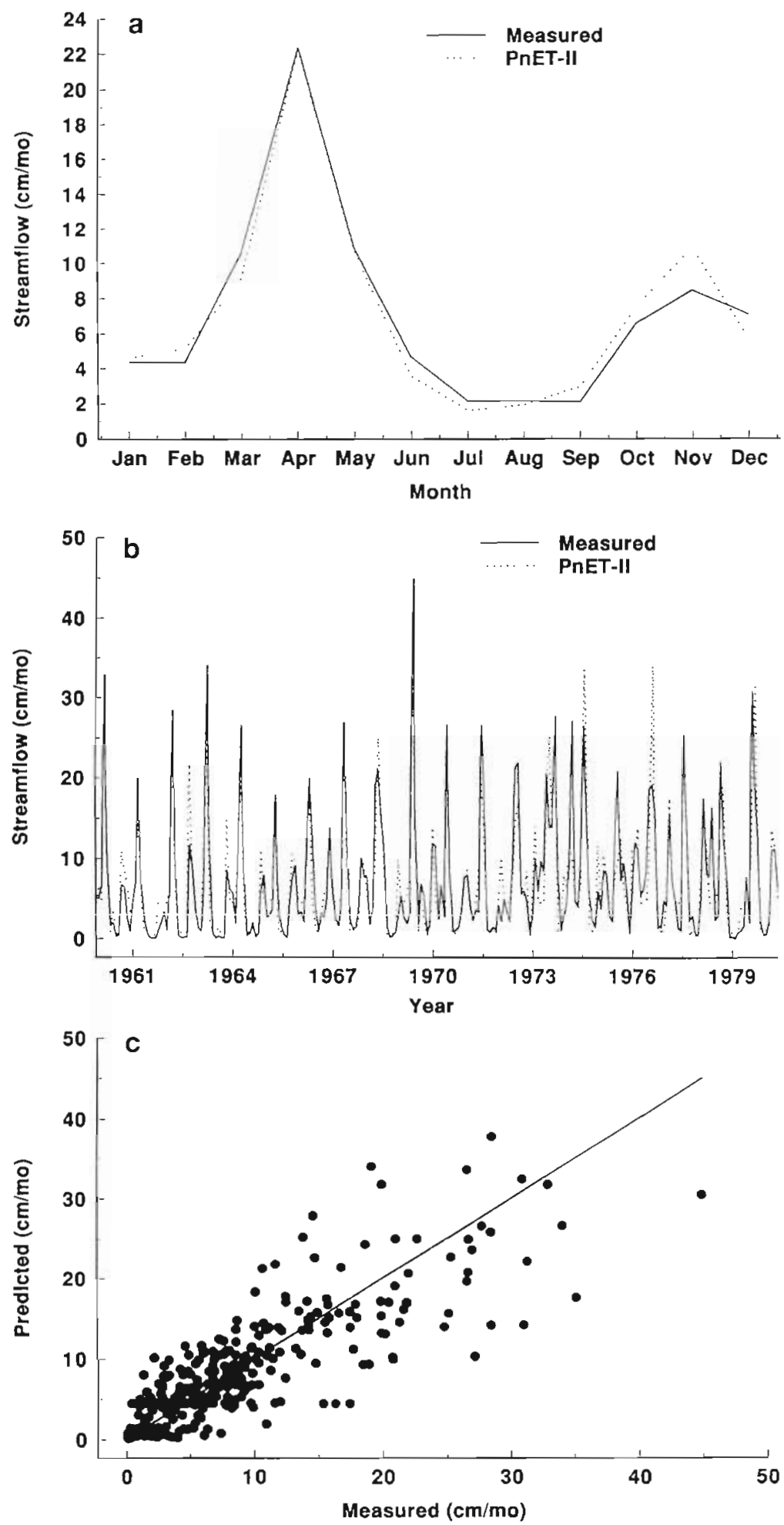

Fig. 3. Comparison of measured (Federer et al. 1990, pers. comm.) and predicted (PnET-II) mean monthly streamflow (water yield) from Watershed 6 at the Hubbard Brook Experimental Forest: (a) means of all monthly values for the years 1957 to 1990 , (b) monthly values for 1960 to 1979 , (c) predicted versus observed for all monthly values. Standard errors in (a) are 5 to $8 \%$ of mean values, and are not shown because of high degree of overlap. None of the differences in (a) are statistically significant $(p>0.05)$ 
Table 6. Predicted and measured biomass production at Whiteface Mountain spruce-fir site (data from Johnson \& Lindberg 1992)

\begin{tabular}{|c|c|c|c|c|c|c|c|}
\hline \multicolumn{4}{|c|}{ Measured } & \multicolumn{4}{|c|}{ PnET-II predicted } \\
\hline Foliage & Wood & Root & Total & Foliage & Wood & Root & Total \\
\hline 221 & 364 & 153 & 738 & 197 & 393 & 175 & 765 \\
\hline
\end{tabular}

\section{Predicted long-term carbon balances}

The evidence presented by Tans et al. (1990) that the northern temperate zone is an important sink for carbon has increased interest in the carbon balances of forests in these regions, and the possible role of $\mathrm{CO}_{2}$ fertilization in stimulating carbon storage. Actual carbon balance data such as are available for the Harvard Forest are rare and difficult to extrapolate over large areas.

\section{Site level}

Annual estimates of total net carbon exchange (= NEP) were developed for the Hubbard Brook and Harvard Forest stands using actual climate time series data. Because of the possible importance of water stress for these balances as discussed above, the Harvard Forest hardwood stand was run using both lim-

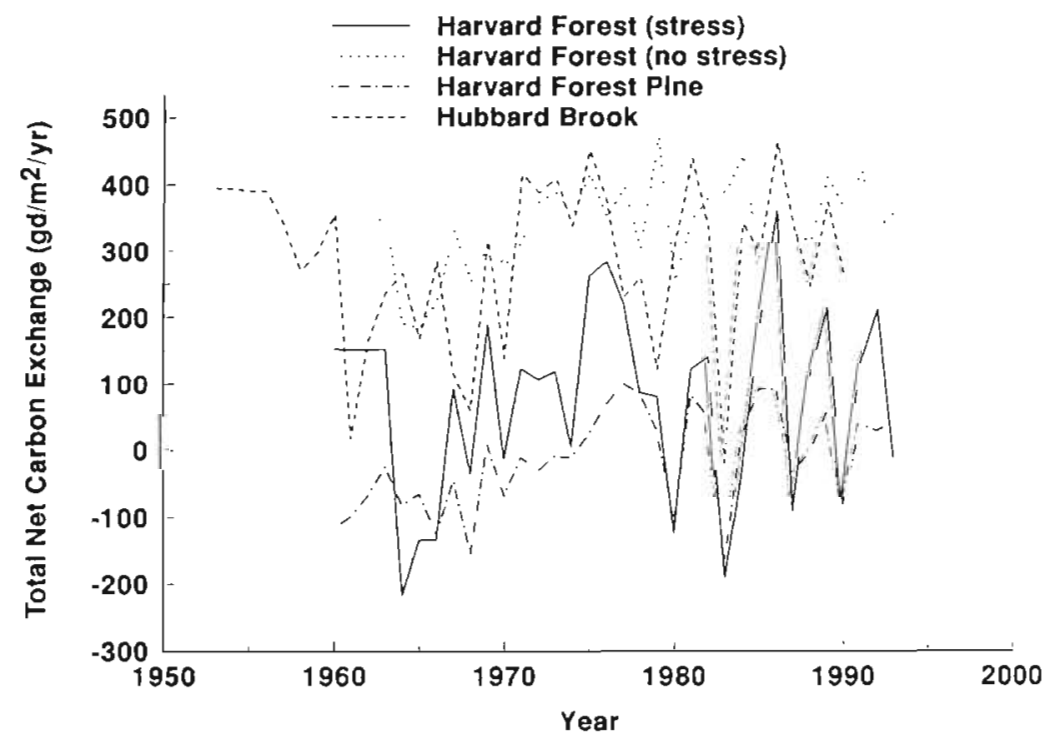

Fig. 4. Long-term net ecosystem production (NEP) predictions for 4 forest/site combinations. Mean values for each are: Hubbard Brook, 287; Harvard Forest hardwood, 55 (with water stress) and 337 (without water stress); Harvard Forest Pine, 59. An additional run with mean climate data for the spruce-fir stand yielded a predicted NEP of 28 (all values in $\mathrm{g} \mathrm{C} \mathrm{m}^{-2} \mathrm{yr}^{-1}$ ) ited and unlimited water availability (Fig. 4). The importance of drought years (e.g. 1968, 1983) can be seen in all series except the no-water-stress Harvard Forest run. Eliminating water stress at the Harvard Forest increased the average annual NEP from 75 to $337 \mathrm{~g} \mathrm{C} \mathrm{m}^{-2} \mathrm{yr}^{-1}$. Hubbard Brook had a predicted average annual NEP similar to that of the unstressed Harvard Forest run $\left(287 \mathrm{~g} \mathrm{C} \mathrm{m}^{-2} \mathrm{yr}^{-1}\right)$. The Harvard Forest pine stand, with lower carbon gain, showed a predicted NEP of $-15 \mathrm{~g} \mathrm{C} \mathrm{m}^{-2} \mathrm{yr}^{-1}$. The spruce-fir data set was run using only mean climatic data, as no time series data were available for the Whiteface Mountain site. NEP under these mean conditions was $28 \mathrm{~g} \mathrm{C}$ $\mathrm{m}^{-2} \mathrm{yr}^{-1}$. All of these runs used the same soil respiration equation developed at the regional scale for all forests.

\section{Regional level}

Predicted NEP values for each forested pixel in the regional GIS were obtained using mean predicted climate variables and mapped land use/land class information as described above. Results show a predicted range of from -150 to $350 \mathrm{~g} \mathrm{C} \mathrm{m}^{-2} \mathrm{yr}^{-1}$ (Fig. 5a), with a mean of $76 \mathrm{~g} \mathrm{C} \mathrm{m}^{-2} \mathrm{yr}^{-1}$. The regional distribution of these values (Fig. 5b) shows that, under current climatic conditions, estimated NEP is highest for hardwood sites at moderate to high elevations and low latitudes (e.g. the Catskill mountain area). This results from both lower soil respiration rates due to lower temperatures, and reduced water stress and higher NPP due to higher precipitation. Lowest values are along the coastal plain region, due in part to a higher proportion of pine stands which achieve lower rates of net photosynthesis and NPP, and in the extreme northwestern edge of the region, which has the lowest precipitation and greatest water stress. Again, these results assume a single relationship between temperature and soil respiration holds for all sites in the region, and that water holding capacity is constant, and water stress significant in some locations. These limitations mean that the regional estimates given here may be subject to change with improvements or refinements in any of these assumptions. Summing estimated net carbon balances for all forested pixels in the region, using the above assumptions, yields a total net carbon gain of $2.3 \times$ $10^{13} \mathrm{~g} \mathrm{C} \mathrm{yr}^{-1}$. 


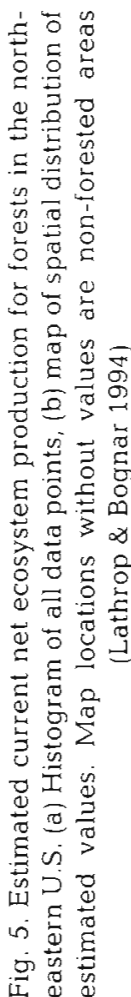
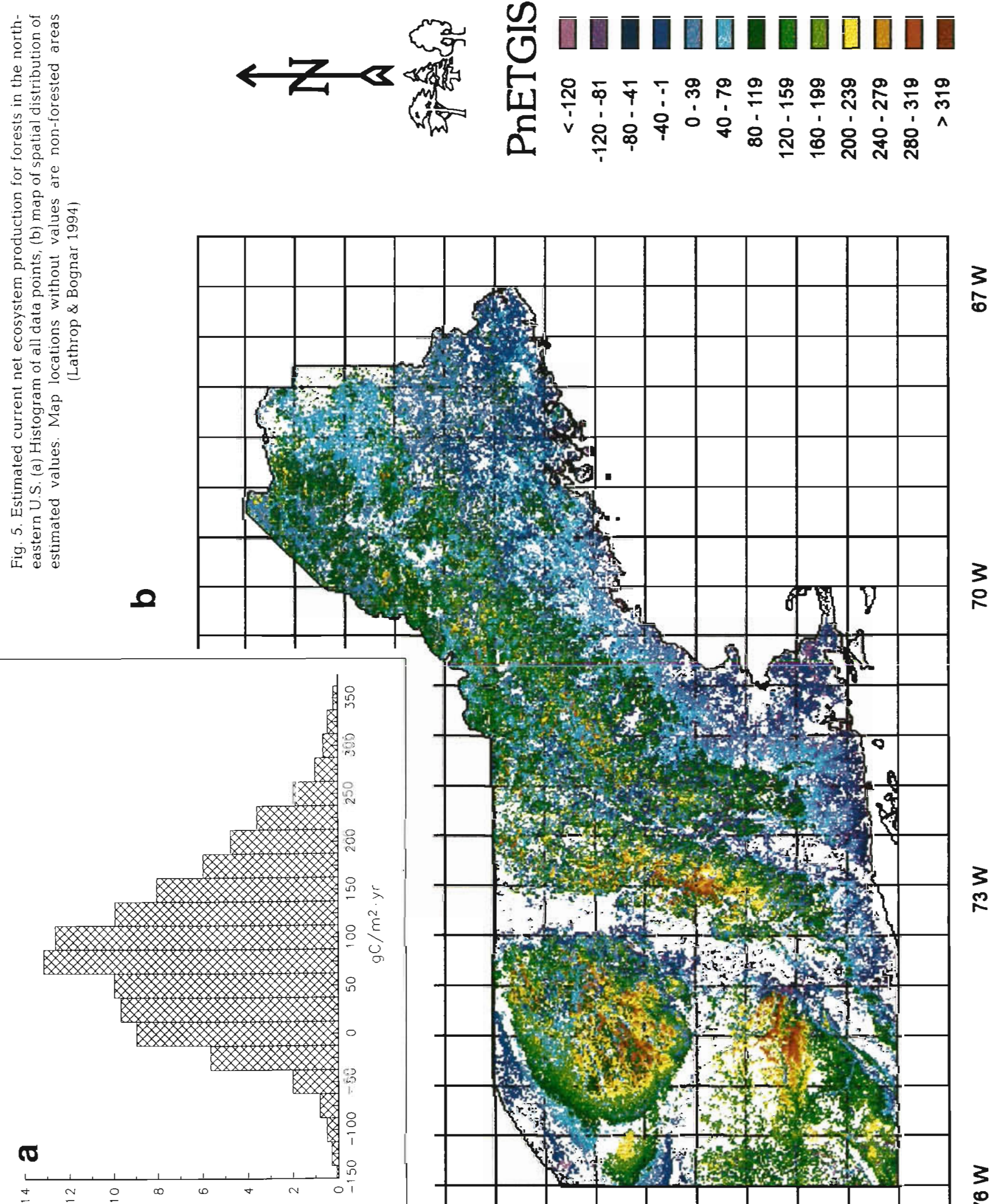

(¿) Kauanbas,

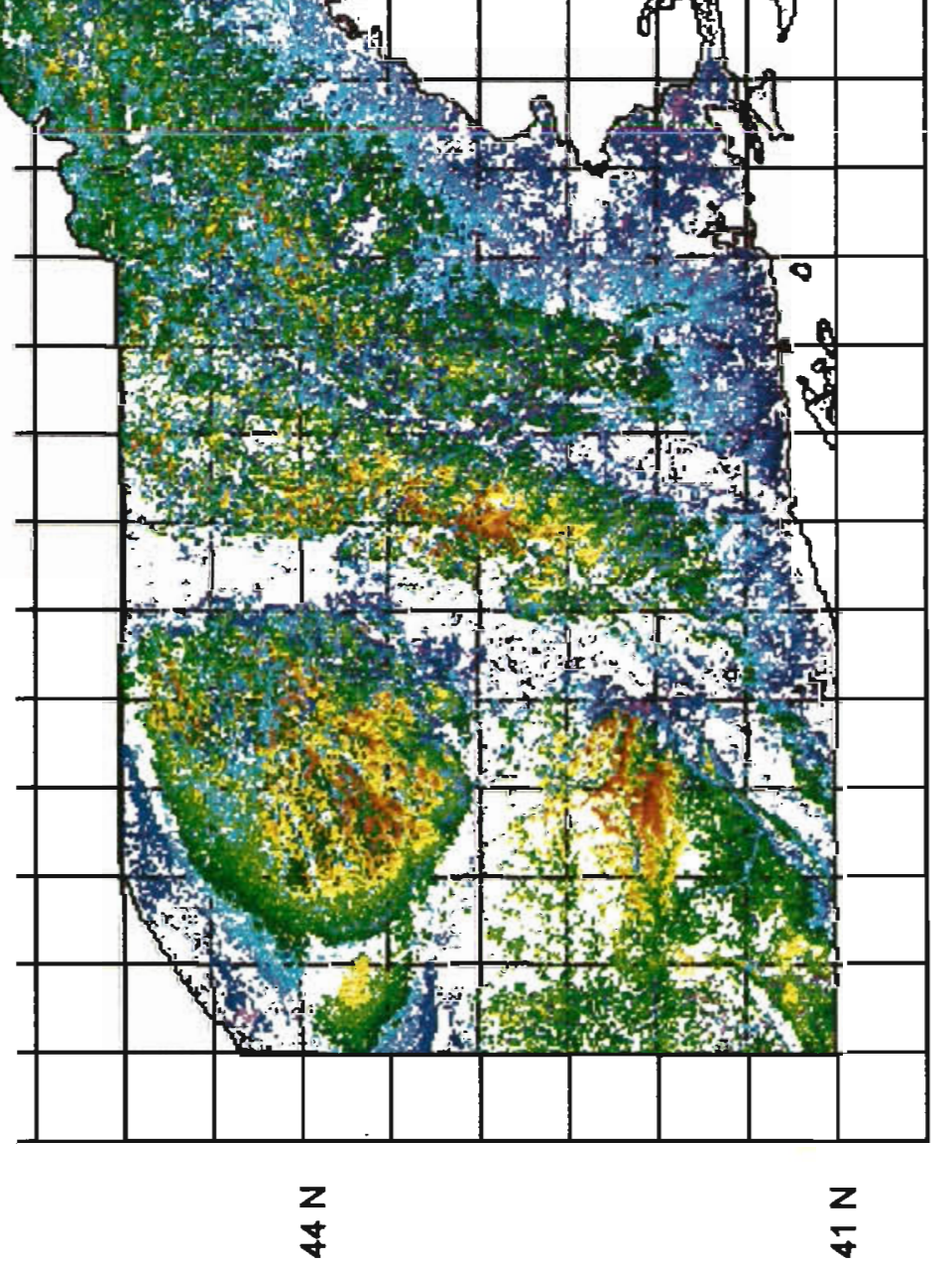



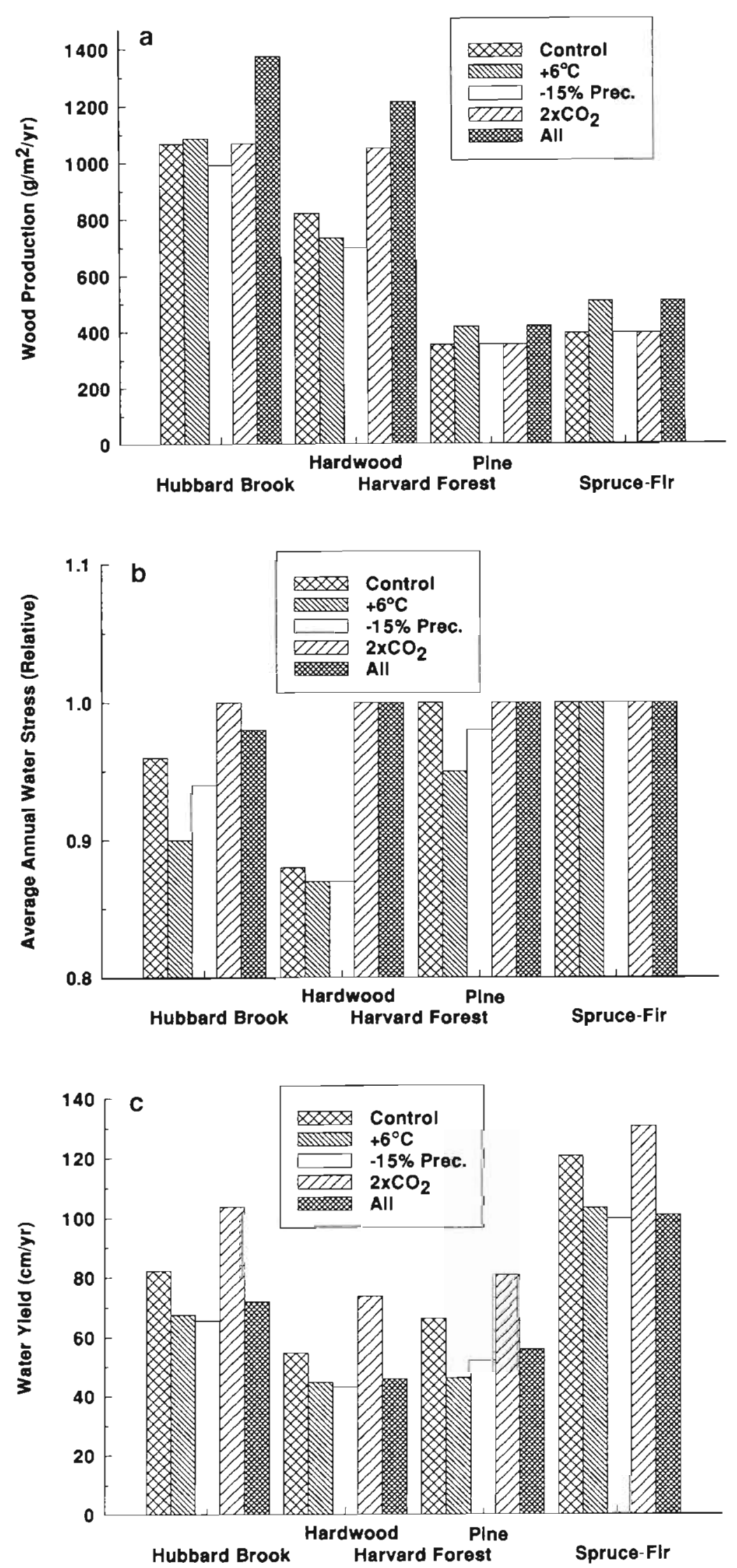

Fig. 6. Estimated effects of individual and combined changes in temperature, precipitation and atmospheric $\mathrm{CO}_{2}$ concentration on: (a) wood production, (b) relative average annual water stress of trees, (c) water yield for 4 forest/site combinations. All Harvard Forest hardwood runs are with water stress. Values are means denved using actual climatic time series data modified as indicated by treatment 


\section{Predicted responses to climate change}

$$
\text { Site level }
$$

The predicted responses to climate change (Fig. 6) were all related to a greater potential for carbon gain, and also for water stress, in the deciduous stands relative to the evergreens. The longer growing season induced by increasing temperature alone increased wood production slightly in all stands, but also increased water stress (where present) and decreased water yield. Decreasing precipitation alone increased water stress in all but the spruce-fir stand, and also decreased wood production and water yield. A doubling of $\mathrm{CO}_{2}$ increased water yield in all stands, removed water stress, and increased wood production where water stress had been present. The combined treatment results in a longer growing season and increased water use efficiency, but with reduced precipitation input. This generally removed water stress and increased wood production (by more than $50 \%$ in the hardwood stands), but with 10 to $15 \%$ reductions in water yield.

\section{Regional level}

Regional patterns of estimated response in wood production to the combined climate change scenario (Fig. 7a) showed largest increases in deciduous stands across the northern portions of the region and in areas where water stress is predicted under current conditions. Lowest increases and slight decreases occurred in low elevation spruce-fir at the southern end of their range. These results indicate a northward shift in the productive capacity of both forest types, with hardwood zones shifted by 5 to $6^{\circ}$ latitude and conifers by approximately $3^{\circ}$.

Under climate change, predicted water yield decreased over most of the region, although this decrease was generally less than the specified decrease in precipitation (Fig. 7b). The largest decrease occurred in hardwood forests experiencing the greatest increase in predicted growth.

This result is the product of several factors that have offsetting effects. The longer growing season and increased net photosynthesis would normally increase annual plant water demand, but the doubled water use efficiency reduces water consumption by a factor of 2 under any given set of conditions. Because the decrease in water yield was less than the decrease in precipitation, we can conclude that the increased water use efficiency outweighed increased growth rates and that the predicted decrease in runoff was caused mostly by the reduction in precipitation. A similar scenario with no change in precipitation would yield a slight increase, rather than decrease, in predicted water yield

\section{CONCLUSIONS}

Comparisons of measured NCE from the Harvard Forest with simulations presented here and in Aber et al. (1995) suggest the importance of accurately specifying water availability to forest stands and predicting the occurrence of water stress. Our current regional extrapolations assume a constant $12 \mathrm{~cm}$ holding capacity of soil water available to plants across the region, which results in significant water stress and reduction in carbon gain for deciduous forests over much of the region. Increasing the accuracy of the soil water holding capacity data plane is an important step in improving the accuracy of the regional predictions. We are currently pursuing validation of PnET-II water yield predictions at the regional scale through comparison with regional extrapolations from gauged watershed data (Bishop \& Church 1992), and regional forest production estimates by comparison with U.S. Forest Service Forest Inventory and Analysis data. The assumption of doubled water use efficiency in a $2 \times \mathrm{CO}_{2}$ atmosphere is also crucial to this conclusion, making this an important area for future research.

Differences between a regionally developed soil respiration equation and locally occurring respiration rates around the eddy correlation tower at the Harvard Forest may have also contributed to the disagreement between predicted and observed NCE in this forest. Still, predicted total annual NCE was within $70 \mathrm{~g} \mathrm{C} \mathrm{m}^{-2}$ $\mathrm{yr}^{-1}$ of observed for all 3 years, an amount representing approximately $7 \%$ of the total annual flux of carbon through the system.

With these limitations, the PnET-II model validates well against available field data on NPP and water yield for the Harvard Forest and Hubbard Brook sites. Predicted changes in regional forest ecosystem function resulting from one published climate change scenario suggest increased wood production and decreased water yield from most forested ecosystems in the region. However, the decrease in water yield resulted mainly from decreased precipitation in the climate change scenario. Without this change, water yields would be similar for the control and climate change scenarios.

Overall, these initial regional predictions suggest increased wood growth and similar to slightly decreased water yield over the northeastern U.S. in response to climate change. The model remains incomplete, however, because 2 other important regional stress factors, ozone and atmospheric deposition, are not included. Future versions of the PnET model will deal with these stress factors explicitly. 

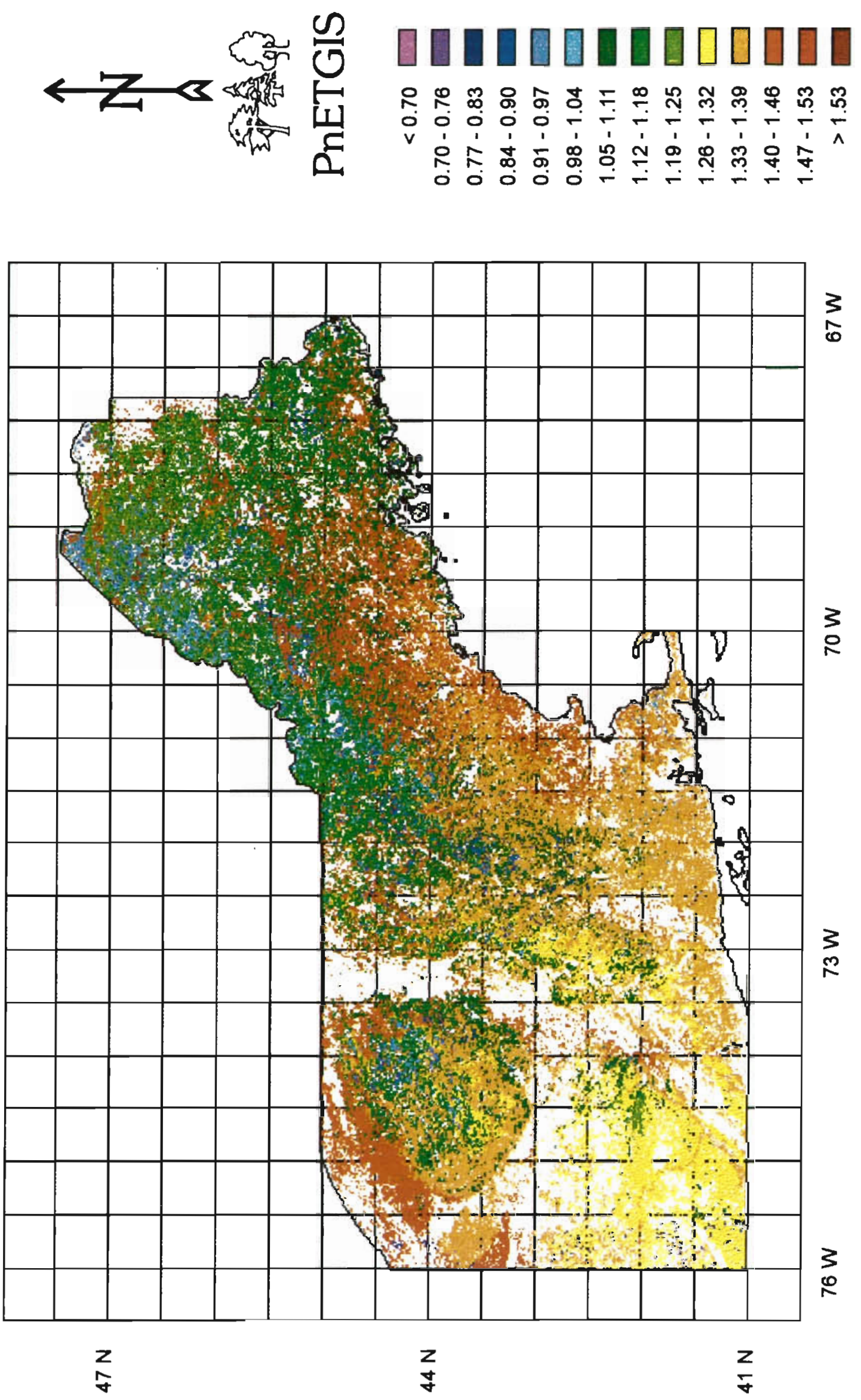


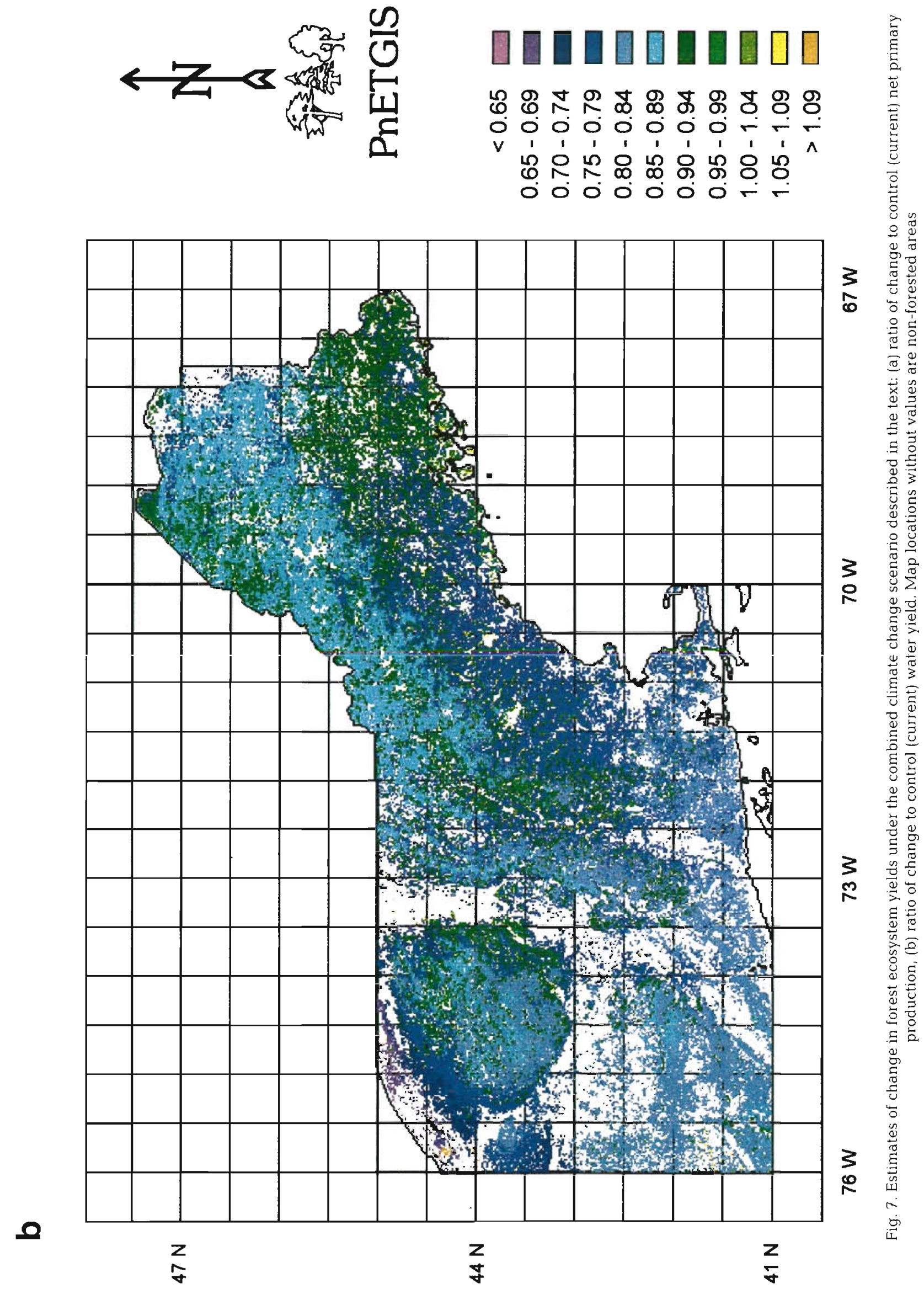


Acknowledgements. This work was supported by the U.S Forest Service Global Change Program for the Northeastern U.S. the U.S. Environmental Protection Agency, and the National Science Foundation Long-Term Ecological Research Program - Harvard Forest Site Project

\section{LITERATURE CITED}

Aber JD, Driscoll C, Federer CA, Lathrop R, Lovett G, Melillo JM, Steudler PA, Vogelmann J (1993a) A strategy for the regional analysis of the effects of physical and chemical climate change on biogeochemical processes in northeastern (US) forests. Ecol Model 67:37-47

Aber JD, Federer CA (1992) A generalized, lumped-parameter model of photosynthesis, evaporation and net primary production in temperate and boreal forest ecosystems. Oecologia 92:463-474

Aber JD, Magill A, Boone R, Melillo JM, Steudler P, Bowden $R$ (1993b) Plant and soil responses to chronic nitrogen additions at the Harvard Forest, Massachusetts. Ecol Appl $3: 156-166$

Aber JD, Reich PB, Goulden ML (1995) Extrapolating leaf $\mathrm{CO}_{2}$ exchange to the canopy: a generalized model of forest photosynthesis compared with measurements by eddy correlation. Oecologia (in press)

Bazzaz FA (1990) The response of natural ecosystems to the rising global $\mathrm{CO}_{2}$ levels. Ann Rev Ecol Syst 21:167-196

Beltz RC, Cost ND, Kingsley NP, Peters JR (1992) Timber volume distribution maps for the eastern United States USDA Forest Service General Technical Report WO-60 Washington, DC

Bishop GD, Church MR (1992) Automated approaches for regional runoff mapping in the northeastern United States. J Hydrol 138:361-383

Burke IC, Kittel TGF, Lauenroth WK, Snook P, Yonker CM, Parton WJ (1991) Regional analysis of the central great plains. BioSci 41:685-692

Covington WW, Aber JD (1980) Leaf production during secondary succession in northern hardwoods Ecology 61. 200-204

Federer CA, Flynn LD, Martin CW, Hornbeck JW, Pierce RS (1990) Thirty years of hydrometeorologic data at the Hubbard Brook Experimental Forest, New Hampshire. USDA US Forest Service General Technical Report NE141, Radnor, PA

Gosz JR, Likens GE, Bormann FH (1972) Nutrient content of litterfall on the Hubbard Brook Experimental Forest, New Hampshire. Ecology 53:769-784

Johnson DW, Lindberg SE (eds) (1992) Atmospheric deposition and forest nutrient cycling. Springer-Verlag, New York

Kicklighter DW, Melillo JM, Peterjohn WT, Rastetter EB, McGuire AD, Steudler PA, Aber JD (1994) Aspects of spatial and temporal aggregation in stimating regional carbon dioxide fluxes from temperate forest soils. J geophys Res 99(D 1): 1303-1315

Lathrop RG, Aber JD, Bognar JA (1995) Spatial variability of digital soil maps in a regional modeling context. Ecol Model 82:1-10

Lathrop RG, Bognar JA (1994) Development and validation of
AVHRR-derived regional cover data for the northeastern US. Int J remote Sensing 15:2695-2702

Likens GE, Bormann FH, Pierce RS, Eaton JS, Johnson NM (1977) Biogeochemistry of a forested ecosystem. SpringerVerlag, New York

Melillo JJ, Callaghan TV, Woodward FI, Salati E, Sinha SK (1990) Effects on ecosystems. In: Houghton JT, Jenkins GJ, Ephraums JJ (eds) Climate change: the IPCC scientific assessment. Cambridge University Press, Cambridge, $p$ $131-172$

Mitchell JFB, Manabe S, Tokioka T, Meleshko V (1990) Equilibrium climate change. 16: Houghton JT, Jenkins GJ, Ephraums JJ (eds) Climate change: the IPCC scientific assessment. Cambridge University Press, Cambridge, $p$ $131-172$

Mooney HA, Drake BG, Luxmore RJ, Oechel WC, Phelka LF (1991) Predicting ecosystem response to elevated $\mathrm{CO}_{2}$ concentrations. BioSci 41:96-104

Ollinger SV, Aber JD, Federer CA, Lovett GM, Ellis J (1995) Modeling physical and chemiscal climatic variables across the northeastern U.S. for a Geographic Information System. US Forest Service General Technical Report NE-191, Radnor, PA.

Ollinger SV, Aber JD, Lovett GM, Millham SE, Lathrop RG (1993) A spatial model of atmospheric deposition for the northeastern U.S. Ecol Appl 3:459-472

Raich JW, Nadelhoffer KJ (1989) Below ground carbon allocation in forest ecosystems: global trends. Ecology 70: $1346-1354$

Raich JW, Rastetter EB, Melillo JM, Kicklighter DW, Steudler PA, Peterson BJ, Grace AL, Moore BM, Vorosmarty CJ (1991) Potential net primary productivity in South America: application of a global model. Ecol Appl 1:399-429

Rastetter EB, Ryan MG, Shaver GR, Melillo JM, Nadelhoffer KJ, Hobbie JE, Aber JD (1991) A general biogeochemical model describing the responses of the $\mathrm{C}$ and $\mathrm{N}$ cycles in terrestrial ecosystems to changes in $\mathrm{CO}_{2}$, climate and $\mathrm{N}$ deposition. Tree Physiol 9:101-126

Running SW, Nemani RR (1991) Regional hydrologic and carbon balance responses of forests resulting from potential climate change. Clim Change 19:349-368

Ryan MG (1991) A simple method for estimating gross carbon budgets for vegetation in forest ecosystems. Tree Physiol 9:255-266

Tans PP, Fung IY, Takahasi T (1990) Observational constraints on the global atmospheric $\mathrm{CO}_{2}$ budget. Science $247: 1431-1438$

Tissue DL, Oechel WC (1987) Physiological response of Eriphorum vaginatum to field elevated $\mathrm{CO}_{2}$ and temperature in the Alaskan tussock tundra. Ecology 68:401-410

USGS (1987) Digital elevation models: data user's guide 5. US Geological Survey, Reston, VA

US Soil Conservation Service (1991) State soil geographic data base (STATSGO) data users guide. US Soil Conservation Service, Washington, DC

Whittaker RH, Bormann FH, Likens GE, Siccama TG (1974) The Hubbard Brook Ecosystem Study: forest biomass and production. Ecol Monogr 44:233-254

Wofsy SC, Goulden ML, Munger JW, Fan SM, Bakwin PS, Duabe BC, Bassow SL, Bazzaz FA (1993) Net exchange of $\mathrm{CO}_{2}$ in a mid-latitude forest. Science 260:1314-1317

Manuscript first received: April 21, 1995

Revised version accepted: August 10, 1995 